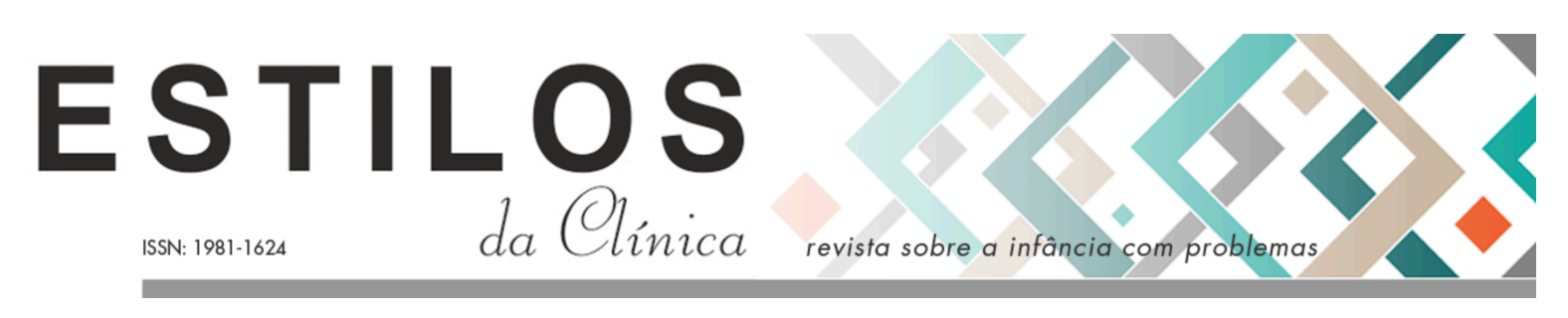

DOI: https://doi.org/10.11606/issn.1981-1624.v24i1p41-52.

\title{
Dossiê
}

\section{As crianças, a educação e os sonhos adultos em tempos de autismo}

\author{
Leandro de Lajonquière ${ }^{1}$
}

Resumo. O imaginário pedagógico contemporâneo estrutura-se em torno de um personagem chamado autista. Trata-se de um ser ficcional que não deve ser confundido com nenhuma criança autista em particular. Isso permite afirmar que vivemos em tempos de autismo que entranham um empobrecimento da vida cotidiana com as crianças de carne e osso. Embora não se possa afirmar o caráter patogênico desse empobrecimento educativo à maneira de um vírus ou conforme o raciocínio determinista clássico "causa-efeito", propomos pensar o imaginário atual como uma espécie de caldo de cultura no interior do qual cada criança confronta-se com o desafio de conquistar por si e para si um lugar de sujeito de palavra numa história mais ou menos aberta para o futuro. A criança bem pode virar vítima de um mal-entendido educativo e assim vir a ficar em certa medida à deriva no mundo. Talvez, pois isso não pode ser sabido, mais de uma criança autista esteja a testemunhar de semelhante infortúnio.

Palavras-chave: autismo; relação adulto-criança; imaginário pedagógico; mal-estar na cultura.

\section{Los niños, la educación y los sueños adultos en tempos de autismo}

Resumen. El imaginario pedagógico contemporáneo se estructura en torno a un personaje llamado autista. Tratase de un ser imaginario que no debe confundirse con ningún niño autista en particular. Esto permite afirmar que vivimos en tiempos de autismo que entrañan un empobrecimiento de la vida cotidiana con los niños de carne y hueso. Aunque no se puede afirmar el carácter patogénico del empobrecimiento educativo a la manera de un virus o del esquema determinista clásico causa-efecto, proponemos pensar como una especie de caldo de cultivo en el interior del cual todo niño se depara con el desafío de conquistar por sí y para sí un lugar de sujeto de palabra en una historia abierta al futuro. El niño bien puede padecer de un malentendido educativo en su calidad de niño autista.

Palabras clave: autismo; relación adulto-niño; imaginario pedagógico; malestar en la cultura.

\section{Children, education and adult dreams in times of autism}

Abstract. The contemporary pedagogical imaginary is structured around a character called autistic. It is a fictional being that should not be confused with any particular autistic child. This allows us to affirm that we live in times of autism that entail an impoverishment of everyday life with the children of flesh and blood. Although the pathogenic nature of this educational impoverishment cannot be affirmed in the manner of a virus or

1. Membro-fundador do Laboratório de Estudos e Pesquisas Psicanalíticas e Educacionais sobre a Infância (Lepsi) da Universidade de São Paulo (USP), São Paulo, SP, Brasil. Orientador de doutorado na Université Paris 8, Saint Denis, França. E-mail: ldelajon@usp.br 
according to the classical deterministic logic "cause-effect", we propose to think of the present imaginary as a kind of breeding ground within which each child confronts the challenge of conquering by him or herself and for him or herself a place of speech in a history somewhat open to the future. The child may become the victim of an educational misunderstanding and thus become somewhat adrift in the world. Perhaps, as this cannot be known, more than one autistic child is witnessing to such misfortune.

Keywords: autism; adult-child relationship; pedagogical imaginary; discomfort in the culture.

Certo tempo atrás ${ }^{1}$ me vi confrontado à pergunta seguinte: "Que crianças deixaremos para o mundo?" O leitor que segue há tempo meu ensino, sabe que não poucas vezes chamado a responder sinteticamente uma pergunta desse tipo - que em bom português bem poderia ser qualificada de cabeluda - costumo responder "Sim e Não". Isto é, primeiro arguo afirmativamente, mas logo apresento a razão pela qual a pergunta mereceria também uma resposta negativa. No entanto, nessa oportunidade, perante a pergunta que me foi colocada, ou seja, aquela sobre quais seriam as crianças que deixaremos para o mundo, acabei respondendo simplesmente que não sabia. No entanto, rapidamente acrescentei que a pergunta me permitia apresentar algumas ideias que estava a pensar nesses mesmos dias e que dizem respeito à forma que temos de viver a vida com as crianças. Neste texto, creio, então, ser oportuno, retomá-las e desenvolvê-las.

\section{Tempos de autismo}

A pergunta sobre quais crianças deixaremos para o mundo é de fato impossível de ser respondida. Se o questionamento apontasse para as crianças do mundo de hoje, talvez fosse mais simples de se responder, embora sempre devamos ter cautela na hora de falarmos sobre as crianças. Depois de tudo, não devemos esquecer que quando falamos de uma criança, estamos de fato a dizer também d'isso que ignoramos de nós mesmos. Esta advertência talvez deva ser considerada uma espécie de regra metodológica número um no nosso campo de pesquisas psicanalíticas na educação. Mais ainda, como d'isso nada queremos saber, então, ficamos a falar d'A Criança (Lajonquière, 2008 abr., 2008 nov., 2009), esse ser imaginário puro estofo de saberes expertos, mas nunca conversamos de fato com uma criança de carne e osso.

O verbo da pergunta em questão está conjugado no tempo futuro. Pretende-se saber, então, sobre as crianças que deixaremos mais na frente. Ela não quer saber destas que estamos deixando hoje para o mundo. Por outro lado, estas de hoje, amanhã serão já grandes e, portanto, já não serão mais crianças. Assim sendo, a pergunta nada quer saber nem destas de hoje, nem do que estas virão a ser amanhã quando grandes. A pergunta aponta para as crianças de amanhã, dessas que ainda não trouxemos de fato, mas que algum dia viremos a deixar para o mundo. Pois bem, para esta pergunta não tenho resposta alguma. Por outro lado, pessoalmente não me surpreenderia se daqui a algum tempo viéssemos simplesmente a parar de trazer crianças para o mundo. A história dos homens já deu até aqui provas de que é capaz de não poucas novidades.

1 Quando da minha participação no XII ${ }^{\circ}$ Coloquio Internacional do Lepsi, realizado em 2017 na USP, numa mesa redonda que levava por título essa mesma pergunta. 
A pergunta que me fora endereçada sobre o ser de crianças que nem sequer ainda trouxemos ao mundo diz de fato de nossa insistência bem adulta e neurótica de virmos a saber sobre as crianças de hoje ou de ontem, pouco importando os tempos. São elas que nos preocupam e nos ocupam, isto é, que enfim tomam o nosso tempo.

O fato de as crianças nos preocuparem e ocuparem nosso tempo é talvez a marca registrada da forma bem moderna que temos de habitarmos o mundo. Aquilo que caracteriza os tempos modernos é a nossa convicção de estarmos a produzir um tempo futuro, um tempo diferente da mesmice daquele já vivido, já gasto. Nos tempos pré-modernos, as crianças eram esperadas no intuito de darem continuidade ao mundo que aí já estava. Porém, aos poucos, as crianças passaram a ser esperadas com vistas a habitarem quando grandes um outro mundo diferente, num tempo futuro aqui mesmo no planeta Terra. Eis aqui a diferença em matéria de espera adulta das crianças e não como se acostumou dizer, há alguns anos, de que nossos ancestrais não amavam seus filhos, a partir de uma leitura apressurada do livro de Philippe Ariès (1960) conforme discorri no X Coloquio Internacional do LEPSI ${ }^{2}$, em 2014.

Assim sendo, nestes novos tempos modernos tencionados para o horizonte, para a frente, se assim podemos dizer, a criança, enquanto ser chegado ao mundo um tempo depois que nós, se faz em princípio credor de um tempo ainda-não, ou seja, de um tempo outro que para nós já será tarde demais. A criança se faz credora de um tempo para nós impossível de ser experimentado. Nesse sentido, digo que a criança dos tempos modernos vira uma espécie de sanduíche entre passado e futuro, pois esse novo tempo associado a um novo sentimento de infância - o futuro - não acaba por desalojar o passado. Então, poder-se-ia afirmar, retomando as palavras de Hannah Arendt a propósito do "abismo da liberdade"3, que o pulsar da temporalidade da infância moderna se desdobra num "não mais e ainda não".

Mais ainda e tendo em vista a proliferação de utensílios e bugigangas de nossa vida cotidiana pós-revolução tecnológica, permito-me afirmar que a criança passou a funcionar de fato como uma invenção muito especial. A criança credora do sentimento moderno de infância vira uma espécie uma máquina para nós - adultos - 'explorarmos o tempo'. Assim, a criança moderna faz com que cada um de nós venha a ter um pouco do herói do livro de Herbert Wells - A Máquina do Tempo, 1895 -, do Dr. Brown do filme De volta para o futuro (1985) do diretor Robert Zemeckis ou de Tony e Doug, os viajantes dessa série norteamericana $O$ túnel do tempo, que assistia na TV na casa de meus avôs ainda pequeno. Entretanto, creio que hoje em dia, nestes tempos recentes que certa $v^{4} z^{4}$ propus de qualificarmos de tempos de autismo, a criança não é mais a nossa máquina para explorarmos ou viajarmos no tempo. Hoje em dia, a criança é sonhada como 'máquina fabricadora de um futuro para um mundo sem passado'. De fato, não é a mesma coisa explorar os tempos ou experimentar a temporalidade que fabricar um pseudo-futuro (Lajonquière, 1999, no prelo). Obviamente, isto não é sem consequências nem para o mundo nem para as nossas crianças de carne e osso, sejam estas de hoje ou aquelas ainda por virem amanhã.

Chegados a este ponto o leitor poderia afirmar que se a criança representa outra coisa para o adulto é porque hoje ela chega diferente à vida. Aliás tão diferente que a suposta quantidade assombrosa de crianças com autismo ou com qualquer outra dessas síndromes que hoje estão

2 Cf. "Notas psicanalíticas para uma outra historia da infância" (2016).

3 Cf. o "Prefácio" de Adriano Correia ao instigante livro de José Sérgio Fonseca de Carvalho (2017).

4 A ideia de qualificar a atualidade de Tempos de Autismo me veio numa conversa com Cristina Kupfer na qual ela buscava um título para o projeto que pretendia apresentar nesse ano de 2015 à FAPESP: Tratar e Educar em Tempos de Autismo. 
na boca de todos, não seria mais que a prova da presença de novas marcas genéticas da espécie humana. Essa diferença no real do organismo faria com que a vida cotidiana com a criança também o fosse. Pode ser que assim seja, mas pode também ser que não, depois de tudo como vir a sabê-lo? Pretender contabilizar todas as crianças, uma por uma, para sabermos que se têm mais ou menos crianças sindrômicas que antes é impossível. Para além do tamanho do levantamento, como estaremos certos de estar contabilizando o mesmo e não coisas parecidas, mas não de fato a mesma coisa? Porém, supondo que mesmo essas impossibilidades resolvidas, ainda teríamos que resolver a questão comparativa com o passado. E aqui já é querer demais! Toda pretensão com vistas a elaborar um saber total sobre os chamados fatores em causa do autismo infantil, ou de qualquer outra dita síndrome, não passa de mais uma tola pretensão que acabará nos lançando contra o famoso dilema, sobre o que veio primeiro: o ovo ou a galinha? Ou seja, vivemos a vida com a criança desse jeito porque é autista? Ou é autista porque vivemos a vida desse jeito com ela? É precisamente aqui onde o pensar estruturalista mostra toda a sua fertilidade. ${ }^{5}$.

No entanto, três coisas são líquidas e certas:

Em primeiro lugar, até agora todas as tentativas de se justificar cientificamente todo tipo de idiossincrasias existenciais acabaram se revelando com o tempo um fiasco. No entanto, assistimos regularmente ao retorno desse mesmo gesto epistemologicamente tosco. Ainda hoje reverbera o clássico debate, reaberto pela publicação, em 1994, de The Bel Courve pelos professores anglo-americanos Richard J. Herrnstein e Charles Murray, sobre a possibilidade de se justificar o desempenho intelectual a partir da ideia de raça. Entretanto, alguns científicos dão provas de inusitada ousadia. Por exemplo, o professor francês de psicologia, nos anos da Segunda Guerra, Léone Bourdel, chegou a justificar o temperamento e gostos musicais nos grupos sanguíneos.

Em segundo, seja qual for a reposta que algum dia venha a ser à problemática da etiologia do autismo, os destinos possíveis de uma criança sempre nos dizem e nos dirão respeito.

E terceiro lugar, hoje, vivemos, sim, tempos de autismo. Falarmos em tempos de autismo não significa dizer que hoje há mais autistas que antes, nem tampouco que o mundo adulto é de fato hoje mais patogênico que antes. A meu ver o problema é o de sempre: como viremos a encontrar um padrão de medida para o mundo e suas transformações? Assim sendo, mais uma vez nos deparamos com a questão ética quando de crianças se trata: O que fazemos ou deixamos de fazer todos os santos dias com elas aqui neste nosso único planeta no sentido de darmos testemunho do desejo que anima a vida com elas?

Não há dúvidas que o autista e suas idiossincrasias passaram a ser objeto de nossa atenção e preocupação. Ainda bem, já era hora! Cabe lembrar que até finais dos anos sessenta as crianças autistas - mas não unicamente elas - não só não frequentavam as escolas seja comuns ou especiais senão que mais ainda eram internadas em asilos. Na França, será Maud Mannoni quem ousará pela primeira vez instalar para as crianças a possibilidade de um outro destino menos funesto, abrindo, em 1969, as portas de Bonneuil como instituição estilhaçada (Lajonquière, 1999). O documentário realizado por Daniel Karlin para a televisão francesa mostra como o espírito asilar ainda convivia, uma década mais tarde, com os hospitais-dia recentemente abertos na esteira do vanguardismo de Bonneuil.

No entanto, hoje estamos tão preocupados pelo autismo - o que infelizmente não significa que estejamos de fato preocupados em fazer alguma coisa interessante com esta ou aquela

5 Um tratamento exaustivo do assunto extrapola os limites deste texto. Sobre o particular o leitor pode consultar de minha autoria o texto "Do interesse epistemológico dos estudos psicanalíticos na educação" (2017a). 
criança autista -, assim como há meio século estávamos preocupados pelos marcianos ou extraterrestres. Como o leitor deve saber sou da época da Mafalda e sua turma ${ }^{6}$, que por sua vez eram contemporâneos do Petit Nicolas e seus amigos ${ }^{7}$. Se o tempo tivesse passado para eles como passou para mim, então, nós teríamos hoje quase a mesma idade. Assim como eles, para além das férias passadas no campo ou na praia, eu também passava as manhãs na escola, mas as tardes as passava na rua ou na praça do bairro brincando e andando de bicicleta com os amigos. Já à noite, era a vez de assistir na TV alguns seriados americanos. Dentre eles, estava aquele sobre os marcianos invasores, um seriado de Larry Cohen dos anos 67 e 68 - The Invaders. Mas, na verdade, os marcianos estavam ou deviam estar por todo lado nessa época e não só dentro de nossas TVs. Astronautas foram enviados à Lua, em 1969, mas lá não os encontraram. No entanto, não perdemos as esperanças de encontrá-los um dia. Assim grandes antenas foram instaladas para espiá-los e escutá-los à distância. Em suma, nos anos sessenta, os extraterrestres nos preocupavam e nos ocupavam. Eles habitavam de fato em nós e, por isso, é que posso dizer que quando pequeno, vivi tempos de marcianos, enquanto hoje, vivo tempos de autismo.

Hoje em dia, o mundo adulto não fica mais tendo que dividir a sua atenção entre os marcianos, por um lado, e as crianças, por outro. De fato, quando pequeno, os adultos ficavam de olho - com um só deles - nas crianças que brincavam na rua e nas praças, mas com o outro, ficavam de olho nos potenciais invasores de outras latitudes. Entretanto, agora o mundo não se interessa mais pelos marcianos. Por outro lado, as ruas e praças, brasileiras e argentinas, perderam suas Mafaldas, seus Petits Nicolas e seus amigos. Já as praças e ruas francesas ainda continuam a acolher-lhos em certa medida como há cinquenta anos ${ }^{8}$.

Que os tempos atuais sejam tempos de autismo significa, então, que este novo personagem chamado autista passou a nos assombrar. Ele está por toda parte. Ele é visto ou esperado até onde ele não está. Por isso, há algum tempo, participo regularmente de bancas de defesa de teses sobre casos clínicos que argumentam sobre como a criança carimbada sumariamente como autista pela escola, por médicos e psiquiatras, responde, entretanto, ao velho figurino da psicose infantil, ou da debilidade etc. Ou seja, hoje, até crianças que talvez possam não ser autistas, são rapidamente rotuladas tais. Nesse sentido, assim como os curas ou padres do filósofo Nietzsche precisavam sempre ter por perto uma alma pecadora, hoje, o mundo adulto, precisa ter às suas voltas 'o autista'.

Porém quem é este novo personagem que nos assombra, que nos faz sombra? O autista que ocupa nosso tempo e tem lugar garantido em nossos sonhos e pesadelos é esse personagem de poucas palavras, que nada pede, que nada demanda, mas que tudo aprende sozinho. Ele não tem amiguinhos e ocupa seu tempo com todo tipo de aparelhos eletrônicos. Por sinal, se estas bugigangas possuem ainda conteúdo pedagógico ou informacional isso é de bom augúrio. $\mathrm{O}$ dito autista processará toda essa informação, todo esse saber-todo graças às suas singulares competências neuro-cognitivas, podendo assim aspirar ao topo da escala, ou seja, a ser um Asperger quando grande.

6 Personagens de história de quadrinhos criados nos anos sessenta pelo cartunista argentino Joaquín Salvador Lavado Tejón, mundialmente conhecido por Quino.

7 Personagens de uma série de contos escritos pelo francês René Goscinny e ilustrados por Jean-Jacques Sempé entre as décadas de cinquenta e sessenta.

8 Alguém me dirá: mas quem sabe por quanto tempo ainda? Mas, bom, deixo os três porquinhos responderem a meu contra arguidor: "enquanto o seu lobo não vem...". 
Este $O$ Autista acabou desalojando os marcianos, as Mafaldas e os Petits Nicolas dos anos sessenta. Ele faz as vezes de ideal em nossos sonhos deste novo século. Esta espécie de criança ideal dos tempos atuais não experimenta mal-estar algum por ser como é, pois não haveria descompasso entre 'ser' e 'estar': ele está onde é, portanto, não 'mal-está' em lugar algum aos olhos adultos. Em suma, este personagem é assim, pois é simplesmente assim. Por outro lado, aprende sozinho, nada demanda e, ainda por cima, com ele não corremos o risco de ter a casa invadida por outros meninos e meninas na volta da escola ou da praça do bairro. Com ele tampouco corremos o risco de ter que organizar festas de aniversários tendo assim que gerir amores, ciúmes e inimizades na hora de ter que escolher um grupo pequeno, dentre os numerosos convidados potenciais. Em certo sentido, este personagem dito autista ocupa, mas não preocupa os pais. Por sinal, é curioso notar que quando se trata de uma criança cujo comportamento corresponde ao do modelo imaginário em voga, os pais não só não manifestam embaraço algum, senão que quando interrogados justificam os comportamentos do filho valendo-se de argumentos que concernem ao mundo dos adultos. Por exemplo, "ela não tem amiguinhas, pois eu tampouco tenho muitas amizades", negando o fato de uma criança nunca brincar com ninguém no pátio da escola não ser equivalente a não ter muitas amizades na vida adulta. Ou também, este outro exemplo, do filho que nunca empresta seus brinquedos para brincar com o primo, e o pai justificar semelhante atitude, interrogando a cunhada desconcertada mãe da outra criança nos termos seguintes: "mas você emprestaria teu laptop?". Nada preocupa a esses pais, pois os filhos nunca aparecem fora de foco. Já outros, cujos filhos não respondem ao figurino imaginário, estão sempre às voltas com suas preocupações mais ou menos justificadas.

\section{Uma educação desproporcionada}

No entanto, devo lembrar que embora este novo personagem imaginário ocupe um lugar de destaque nos sonhos adultos, isso não faz com que as crianças sejam de fato autistas - e volto a insistir, entendamos o que entendamos por esta palavra.

Entre as crianças e o mundo não há proporção, do mesmo modo que, por outro lado, não há relação (rapport) sexual no dizer de Lacan. Ou seja, entre a criança e o mundo há uma diferença irredutível. Isto faz que uma educação ordinariamente boa - parafraseando ${ }^{9} \mathrm{D}$. Winnicott - ou simplesmente uma educação à seco, conforme propusera passando a limpo minhas conversas com Maud Mannoni (Lajonquière, 1999) (Rodrigues \& Reis, 2018), é em ultima instância 'desproporcionada'. Mas esta afirmação também é válida em se tratando seja de jovens ou de adultos, pois embora não haja oposição entre o indivíduo e o social, há de fato solução de continuidade entre o Sujeito e o Outro. A meu entender, isto é importante de ser lembrado pois não poucos no campo dos estudos psicanalíticos na educação recorrem às descrições apocalípticas as mais variadas. Nestas o sujeito é um apêndice do social e, portanto, essas descrições acabam reduzindo nossos sonhos e pesadelos à realidade cotidiana dos laços sociais. O sujeito é precisamente essa diferença no interior mesmo do Outro que instala a possibilidade para o humano em quem ele virá de fato a operar, de não ser o duplo do

9 A tradução habitual da ideia de Winnicott é "uma mãe suficientemente boa". Entretanto, recorro ao uso do termo "ordinário" cuja uma das suas acepções em português significa "por via de regra". 
Outro, seu replicante ou um simples apêndice. Na psicanálise o sujeito é uma diferença no mundo e, nesse sentido, se diz que ele não tem um estatuto ôntico.

O fato de sublinharmos a falta de proporção entre cada humano e o mundo é importante, pois embora possa se dizer que o laço social neste último século bem possa, por exemplo, ser qualificado de perverso, conforme a já clássica reflexão de Calligaris (1986), isso não faz de cada um de nós - adultos - um perverso, nem de todas as crianças, psicóticos. De fato, a maioria dos mundanos seja qual for o mundo ${ }^{10}$ é sempre constituída por neuróticos, mais ou menos propensos a cair em dispositivos perversos, ou seja, no conto do vigário. Porém quem diz maioria não diz nem a totalidade, nem tampouco diz do preço que foi pago por aquele em particular que conseguiu escapar a um destino funesto na empresa de se fazer um lugar de palavra no mundo. Em suma, embora a humanidade não responda a programação taylorista alguma, a questão ética está sempre embutida no laço social. Mais ainda, é por isso que em matéria educativa, embora a psicanálise não possa responder a costumeira demanda pedagógica neurótica do que deve ser feito, ela bem lembra aquilo que justamente não deve ser feito sob pena de fazer da educação de uma criança um fato de difícil acontecimento (Lajonquière, 1999, 2000). A sujeição de uma criança ao desejo não constitui uma meta pedagógica, se por meta entende-se uma resolução do tipo ensinar os números no intuito de a criança saber contar. A sujeição ao desejo é o próprio estofo da educação. Educar é simplesmente humanizar. Em outras palavras, é aquilo que o homem adulto sempre soube fazer sem saber no decorrer dos tempos.

Entretanto, toda educação não pode não ser imperfeita pois não há educação senão no interior do campo da palavra e da linguagem. Mas por outro lado, ela tampouco pode não ser imperfeita, na medida em que os adultos nada querendo saber dessa imperfeição tem o (mau)hábito de se refugiarem em formulações pedagógicas ilusórias. E isto é o que interessa a um psicanalista "aplicado" à educação (Lajonquière, 2009, 2017b) pois essa queda adulta pelas ilusões pedagógicas não é sem consequências para as crianças. Sobre o particular é conhecida a afirmação freudiana: "a educação se conduz como se enviara para uma expedição polar gente vestida com roupa de verão e munida com mapas dos lagos italianos" Freud (1930, p. 3060). Em outras palavras, o mundo adulto não consegue de fato "acertar na mosca" em matéria educativa. No entanto, não por isso uma criança está a priori condenada a perecer numa excursão semelhante, pudendo vir a "dar a volta por cima" da família e da escola. Tal coisa não tem nada de surpreendente pois toda criança vê-se confrontada com o desafio de inverter a demanda educativa adulta para além do fato de que ela seja mais ou menos enlouquecida. Como tal coisa é possível? Tudo dependerá da maneira de como a criança consiga focar o desejo no horizonte da experiencia educativa, ou seja, a castração no Outro. Esta operação exige de toda criança uma implicação subjetiva singular. Porém, é certo que há tanto famílias quanto dispositivos escolares menos perversos que outros no sentido que o preço cobrado para que a criança venha a se autorizar a inverter a demanda adulta é psiquicamente menos desproporcionada (Lajonquière, 1999, 2009).

Toda criança quando chega ao mundo não é biologicamente mais que um pedaço de carne, ossos e alguns cabelos, tomado nas leis da vida humana das células. Justamente, a vida

10 Não há um mundo único, há mundos num único planeta Terra. Portanto, aquilo com o qual cada criança deve se confrontar na sua empresa de vir a conquistar para si um lugar de enunciação, assim como o trabalho realizado para tanto não necessariamente se equivalem. Por sinal, fato não necessariamente tido em conta em não poucas reflexões psicanalíticas na educação que se referem, por exemplo, à experiência escolar como se fosse a mesma em todas as latitudes (Lajonquière, 2019) (Rodrigues \& Reis, 2018). Por sinal, eis aqui talvez a regra metodológica número dois nas pesquisas psicanalíticas na educação. 
humana - à diferença da vida animal das células que se basta a si mesma - é animada por uma "apetência simbólica" conforme a expressão de Crespin (2007). Esta dá nome à orfandade biológica na qual chega todo bebê ao mundo e que o lança à procura de uma complementação que revela ser impossível (Lajonquière, 2009). Em outras palavras, esse estado de prematuração radical faz com que todo bebê se depare imediatamente com o real do mundo. É precisamente por isso que sendo "todo ouvido", "todo olhar", "todo chupar" qualquer bebê é candidato para toda saga educativa - assim como em português dizemos que alguém é pau para toda obra. Assim sendo, isso que costumamos chamar de desenvolvimento psicológico não trata da passagem de um ser egocêntrico ou fechado sobre si-mesmo para um outro mais social, mais desenvolvido, aberto ao mundo e competente no trato do real. $\mathrm{O}$ adulto suposto ter atingido o ápice do desenvolvimento psicológico conforme o pensamento psicopedagógico hegemônico, diferentemente da criança sempre acordada para o real, prefere seguir sonhando acordado graças ao fantasma - espécie de filtro para com o real. Dessa forma, toda educação implica na perda desse acesso direto ao real e, portanto, numa perda da fruição real. Em suma, toda educação que se preze entranha uma perda de gozo.

Que uma educação venha a acontecer é imponderável. Ela reclama como condição necessária, mas não suficiente, a intervenção adulta. Os adultos que venham a animar a educação que insisto em chamar de primordial, por oposição a essa outra segunda no tempo, a educação mais ou menos escolar, são de fato os merecedores do título de pais da criatura. A intervenção educativa é norteada pela suposição inconsciente por parte dos pais de que um desejo deve operar 'no' bebê ou, em outras palavras, de que um sujeito é suposto suportar esse saber-bebê com o qual eles se deparam cotidianamente.

Nesse sentido, afirmei em Infância e Ilusão (psico)Pedagógica (1999) que educar é transmitir marcas simbólicas que possibilitem à criança conquistar para si um lugar numa história, mais ou menos familiar, a partir da qual possa implicar-se nas empresas impossíveis do desejo. Em Figuras do Infantil (2009) esclareci ainda que a educação visa à conquista por parte da própria criança de um lugar de palavra, de um lugar de enunciação numa história em curso. Isto é importante, pois a imponderabilidade dos resultados educativos resulta do entrecruzamento do fantasma educativo inconsciente posto em ato pelos pais, bem como da escolha inconsciente do bebê como sujeito - isto é, do que ele consiga de fato fazer com aquilo que a palavra adulta disponibiliza além da mais ou menos boa vontade parental. Em outras palavras, a educação produz um efeito sujeito que por sua vez cavouca a sua própria enunciação no Outro. Em suma, a educação arrimada ao discurso do mestre (Lacan, 1991) acaba estruturando uma incompletude, conforme afirmo há tempo ${ }^{11}$.

Se o objetivo visado inconscientemente por uma educação é o efeito "sujeito do desejo", então, a educação sempre pode em princípio acontecer ou vingar até que venha a se mostrar infelizmente o contrário. Isto coloca em evidência tanto a passagem do tempo da vida quanto do tempo feito causa estrutural (Lajonquière, 2017a). Por essa razão, sou solidário com os colegas, e muito especialmente, com Cristina Kupfer, na batalha pela intervenção profissional a tempo na infância esclarecida pela psicanálise, ou seja, antes que seja tarde demais ${ }^{12}$. Mas

11 No nosso campo e, particularmente no Brasil, é hábito considerar, ao instar de algumas afirmações lacanianas, o laço educativo como arrimado ao discurso universitário. Porém este diz da estruturação de todo laço tomado naquilo que batizei de ilusão psicopedagógica (Lajonquière, 1997). Mais ainda, esses colegas iludem-se em propor um outro tipo de laço educativo agora arrimado ao discurso do analista, pois devemos lembrar que já Freud observou que toda análise se segue à educação, na vida de qualquer um de nós (Lajonquière, 1999, 2009, 2017a, 2017b).

12 Cf. Kupfer e Bernardino, 2018 jan./abr. Cf. Lajonquière, 2018 jan./abr. 
se esse intervir é simplesmente um intervir apressado, no sentido de se evitar a suposta propagação endémica de uma tara psíquica e/ou orgânica qualquer, então, a intervenção profissional bem pode acabar escorregando para uma espécie de psico-eugenismo higienista. Ao contrario a meu entender o intervir antes que seja tarde demais junto a uma criança é inerente à ética psicanalítica que supõe que toda criança às voltas com uma infância difícil ${ }^{13}$ bem pode (a)travess(e)ar esse tempo em condições outras vindo, assim, a fugir a um destino funesto ${ }^{14}$.

Quando a intervenção dos adultos junto às crianças está atravessada pela recusa inconsciente do desejo, a educação pode tornar-se um fato de difícil acontecimento. A criança passa a ter que remar contra a corrente para, assim, vir a triunfar no reconhecimento inconsciente da sujeição ao desejo ou, em outras palavras, na conquista de um lugar de palavra numa história em curso. Porém, isso não significa a priori que venha a ser impossível para uma criança chegar a bom porto, pois ela bem pode acabar relevando o desafio nem que seja obtendo uma vitória de Pirro. Por outro lado, a eleição inconsciente suportada pelo bebê pode pender para o sentido contrário, embora estejam dadas as condições necessárias para uma boa travessia. Neste caso, a educação pode também acabar se revelando um fracasso. A psicopatologia grave na infância é o infeliz exemplo desses casos e, portanto, bem pode ser pensada como um simples mal-entendido educativo resultado da somatória de um 50\% aportado pelos pais e dos outros $50 \%$ pela criança.

Educar para o desejo é aquilo que o homem comum sabe fazer - embora sem o saber desde sempre quando de crianças se trata. Freud afirmava que a humanidade até esse momento tinha sabido cumprir essa tarefa mesmo que de forma imperfeita. O empecilho para tanto era na época e no entender de Freud os votos pedagógicos totalitários ora inspirados na religião, ora no nazismo, ora no estalinismo (Lajonquière, 2009, 2017b). Bom, hoje em dia, o empecilho é o justificacionismo tecnocientífico imperante no ideário pedagógico hegemônico que povoa os sonhos adultos. Porém, devo dizer que não faço a menor ideia de qual será o empecilho no futuro. No entanto, é certo que nós adultos saberemos amarrar nossa vida junto às crianças em torno de algum novo empecimento, pois ao mundo cotidiano sempre lhe falta algo para ser ideal ${ }^{15}$ (Lajonquière, 2019).

No ideário pedagógico impera, já há algumas décadas, certo justificacionismo - tudo o que acontece na vida junto às crianças, seja em casa, seja na escola, é decifrado e 'justificado' graças a uma hermenêutica psico-socio-lógica qualquer. Por exemplo, as crianças não fazem mais travessuras merecedoras de um corretivo qualquer, elas padecem de um deficit de atenção, objeto de resignação parental e boas doses de Ritalina. Ou - pensa-se - que elas são como são porque agora são sócio-historicamente deste outro jeito. Em contrapartida, boa parte dos pais não pedem mais para seus filhos fazerem coisas consideradas simples obrigações filiais. Não poucos pais não falam mais com seus filhos no intuito de lhes transmitirem ideais sejam os quais forem. Os pais hoje em dia estimulam o desenvolvimento de competências

13 Falar em termos de infância difícil ou infância com problemas (aliás, trata-se do título deste periódico) não equivale a se valer do clássico sintagma criança com problemas. O que é difícil de se viver é a mesmíssima experiência da infância.

14 Por sinal, suposição totalmente sintónica com um espírito democrático e moderno de bem-estar social que se preze, mas infelizmente ausente em sociedades que assumem formas políticas oligarcas e reacionárias.

15 Diferença que não poucos colegas teimam em não reconhecer. Assim, pretendem fazer passar por resultado de pesquisa psicanalítica na educação uma série de comentários ditos críticos em matéria educativa que estão mais para comentários de senhoras reunidas na hora do chá e ofuscadas com os supostos descaminhos da vida de todos os dias à luz (ou sob a sombra) de algum topus teórico-virginal qualquer. 
seguindo as prescrições de manuais os mais variados e, assim, eles nada querem saber do impossível em causa na relação filial.

O horizonte pedagógico atual é tomado ou atravessado ora por noções ou ideias de cunho sociologizantes, ora biologizantes, ora psicologizantes. Seja como for, o ideário amarra-se em torno daquilo que chamei de ilusão psicopedagógica. No entanto, esclareço que as crenças hegemônicas não precisam ser oriundas de alguma psicologia em particular. Isso é detalhe. $\mathrm{O}$ que entendemos por ilusão é a crença tanto na possibilidade quanto na necessidade de adaptarmos ou ajustarmos a educação a um sempre suposto ser infantil já dado que nada deve aos sonhos do mundo adulto. A ilusão psicopedagógica é o sonho de um mundo de harmonia pré-estabelecida. Assim sendo, tal ilusão tem tanta atualidade hoje, nestes tempos de autismo, como há vinte e cinco anos quando falei dela pela primeira vez em plena euforia pedagógicosocio-construtivista.

Neste contexto, afirmo que o personagem destes tempos de autismo - essa criança solitária que aprende sozinha e que nada demanda - é de fato a criança ideal do discurso psicopedagógico ainda hoje hegemônico. Trata-se de uma criança feita puro saber sem 'sujeito suposto' e, portanto, efeito da recusa do desejo em causa no laço educativo. Assim, a intervenção adulta deve fazer sabia-comunhão com esse outro saber acéfalo. Nesse sentido, não devemos nos surpreender que os professores atuais sonhem a própria profissão no simples registro duma transmissão comunicacional de saberes ou conhecimentos ${ }^{16}$.

Estes tempos de autismos atuais não propiciam que o adulto venha a interrogar $\mathrm{o}$ impossível em torno do qual se articula sua própria relação à criança. O fundamentalismo pedagógico psico-sócio-natural é na linha dos ganhos religiosos de antanho, capaz de erradicar a vontade de saber sobre si mesmo, bem como de mitigar o medo dos adultos perante os perigos e as vicissitudes da vida familiar ou escolar junto às crianças, na medida em que formula prescrições, proibições e restrições sempre justificadas. O tecno-cientificismo pedagógico consola pais e pedagogos, bem como anestesia espíritos e corações adultos, na tentativa sempre vã de suturar o desejo que - à sua enigmática maneira - anima a vida junto às crianças.

O tecno-cientificismo de nossos dias não é o laicismo da vida cotidiana tão esperado por Freud no seu "O futuro de uma ilusão" (1927). Trata-se infelizmente de mais ou menos o mesmo de sempre. Porém, num ponto, as ilusões tecno-cientificistas da pedagogia atual se diferenciam das ilusões religiosas da pedagogia da época de Freud. A insistência religiosa em dominar o desejo, como toda neurose, não faz senão colocar uma e outra vez o sujeito numa mesma encruzilhada, qual seja, aquela do reconhecimento de sua impossível realidade. A religião, à diferença do justificacionismo tecnocientífico, não recusa a realidade do desejo: condena o sujeito à reiteração do fracasso do recalque. Nesse sentido, Freud (1932) afirmava que essa "neurose coletiva" que tomava conta do mundo adulto na sua época instalava a possibilidade de as crianças virem no futuro a se colocar do lado dos "inimigos do progresso".

Entretanto, a recusa do desejo, implicada na ilusão psicopedagógica contemporânea, dá margem às crianças virem a adoecer de resignado cinismo, como Freud alertara, mas também de virem a encorpar esse sonhado personagem de ficção $O$ autista.

16 Onde a transmissão de saberes escolares ainda goza de prestigio como na França, o docente fantasia ser uma espécie de antena transmissora de informação para seres aflitos em apreender ou, caso contrário, refratários à mesma (Lajonquière, 2019). 


\section{Concluindo}

Toda contabilidade à maneira de se registrar os casos de gripe em tempos de epidemia, revela ser impossível em matéria educativa. Em suma, é impossível afirmarmos que hoje haveria mais crianças acometidas de autismos do que antes. No entanto, devemos reconhecer que num mundo que 'cheira a autismo', as chances de uma criança embaralhar-se no trabalho de conquista de um lugar de enunciação em nome próprio deveriam em principio aumentar. $\mathrm{O}$ retorno do desejo no bojo do encontro desencontrado que toda e qualquer educação entranha em si mesma, abre as portas para o adulto vir a explorar os tempos. Porém, a criança ideal da ilusão psicopedagógica nestes tempos de autismo vem a fecha-las. O sonho de uma criança solitária que aprende sozinha e nada demanda permite ao adulto iludir-se com a possibilidade de vir a se desvencilhar de toda e qualquer lembrança de infância, bem como de estar a fabricar 'um futuro sem passado'. Em outras palavras, esta nova criança ideal acaba embaralhando a dialética encontro-desencontro com a criança de todos os dias e, assim, ela participa na deflação do jogo da temporalidade no bojo da demanda educativa adulta.

Enfim, o sonho dessa criança 'feita futuro no presente' poupa aos pais de terem que trabalhar simplesmente como pais, simples filhos de outros pais, atravessados pelo dever de suportar em carne própria a suposição inconsciente embalada em sonhos de que um desejo deve operar no filho. Esta pretendida economia de trabalho psíquico por parte dos adultos, sempre foi, é e será de mal augúrio para toda criança que ao mundo chegar. No entanto, devemos ter claro que afirmarmos isso, não significa dizer que nestes tempos de autismo há mais, ou menos, crianças autistas que antes ou que amanhã.

\section{Referências}

Ariès, Ph. (1973). L'enfant et la vie familiale sous l'Ancien Régime. Paris: Seuil. (Trabalho original publicado em 1960)

Calligaris, C. (1986). Perversão um laço social? - Conferência em Salvador. Salvador: Publicação da Cooperativa Cultural Jacques Lacan.

Carvalho F. J. S. (de). (2017). Educação, uma herança sem testamento. São Paulo: Perspetiva: Fapesp.

Crespin, G. (2007). L'épopée symbolique du nouveau-né. Toulouse: Erès.

Freud, S. (1973). El porvenir de una ilusión. In S. Freud Obras completas (Lopez-Ballesteros, trad., Vol. 3, pp. 2961-2992). Madri: Biblioteca Nueva. (Trabalho original publicado em 1927)

Freud, S. (1973). El malestar en la cultura. In S. Freud Obras completas (Lopez-Ballesteros, trad., Vol. 3, pp. 3017-3067). Madri: Biblioteca Nueva. (Trabalho original publicado em 1930)

Freud, S. (1973). Lección 34 Aclaraciones, aplicaciones y observaciones. Nuevas lecciones introductorias al psicoanálisis. In S. Freud Obras completas (Lopez-Ballesteros, trad., Vol.3, pp. 3178-3190). Madri: Biblioteca Nueva. (Trabalho original publicado em 1932)

Karlin, D. (Documentarista). (1977). Les années de la mise au monde. Documentário de 135 minutos realizado para a televisão francesa.

Kupfer, M. C. \& Bernardino, L. M. F. (2018, jan./abr.). IRDI: um instrumento que leva a psicanálise à polis. Estilos da Clínica, 23(1), pp. 62-82. doi: https://doi.org/10.11606/issn.1981-1624.v23i1p6282 
Lacan, J. (1991). Le Séminaire. Livre XVII: L'envers de la psychanalyse. Paris: Seuil (Apresentação oral em 1969-70).

Lajonquière, L. (de). (1997). Dos erros e em especial daquele de renunciar à educação. Estilos da Clínica, 2, 26-43.

Lajonquière, L. (de). (1999). Infância e ilusão (psico)pedagógica. Petrópolis: Vozes.

Lajonquière, L. (de). (2000). Itard victor! Ou do que não deve ser feito na educação das crianças. In L. Banks-Leite, \& I. Galvão (Orgs.) A Educação de um Selvagem: sobre as experiências de Jean Itard (pp. 105-122). São Paulo: Cortez.

Lajonquière, L. (de). (2008, abr.). Niños extraños. En Cursiva. Revista Temática (Buenos Aires), 4, 41-46.

Lajonquiere, L. (de). (2008, nov.). De como jogamos fora a criança com a agua suja do amorodio. Trabalho apresentando no $7^{\circ}$ Coloquio Internacional do LEPSI, São Paulo. Recuperado de http://www.proceedings.scielo.br/scielo.php?script=sci_arttext\&pid=MSC00000000320080001000 $09 \& \operatorname{lng}=\mathrm{pt} \& \mathrm{nrm}=\mathrm{i}$ so\&tlng $=\mathrm{pt}$.

Lajonquière, L. (de). (2009). Figuras do infantil. Petrópolis: Vozes.

Lajonquière, L. (de). (2011). A mestria da palavra e a formação de professores. Educação \& Realidade, 36 (3), 849-865. Recuperado de http://www.ufrgs.br/edu_realidade;

Lajonquière, L. (de). (2013). A palavra e as condições da educação escolar. Educação \& Realidade, 38 (1), 455-469. doi: http://dx.doi.org/10.1590/S2175-62362013000200006

Lajonquière, L. (de). (2016). Notas psicanalíticas para uma outra historia da infância. In R. Voltolini Crianças públicas, adultos privados (pp. 73-84). São Paulo: Escuta/Fapesp.

Lajonquière, L. (de). (2017a). Do interesse epistemológico dos estudos psicanalíticos na educação. In M. R. Pereira (Org.). Os sintomas na educação de hoje. Que fazemos com 'isso'? (pp. 32-38). Belo Horizonte: Scriptum.

Lajonquière, L. (de). (2017b). Sigmund Freud e o interesse pedagógico da psicanalise. In D. Kupermann (Org.). Por que Freud. Hoje? (pp. 243-264). São Paulo: Zagadoni.

Lajonquière, L. (de). (2018, jan./abr.). A psicanálise, os psicanalistas e a polis (Editorial dossiê). Estilos da Clínica, 23(1), pp. 12-14. doi: https://doi.org/10.11606/issn.1981-1624.v23i1p12-14

Lajonquière, L.(de). (2019). Quando o sonho cessa e a ilusão psicopedagógica nos invade, a escola entra em crise: notas comparativas Argentina, Brasil, França. ETD - Educação Temática Digital, 21 (2), 297-315.

Lajonquière, L. (de). (no prelo). Des réminiscences, de la vérité et de l'histoire chez Freud. Analyse Freudienne Presse, 26.

Rodrigues, R.; Reis, M. (2018). A ilusão (psico)pedagógica e o empobrecimento das experiencias educativas (Entrevista com Leandro de Lajonquière). Estilos da Clínica, 23 (2), pp. 430-450. doi: https://doi.org/10.11606/issn.1981-1624.v23i2p430-450 